\title{
Lives after death
}

\section{Alexander von Humboldt: A Metabiography by Nicolaas A. Rupke \\ Peter Berg: 2005. 320 pp. \$38.95, £22.80, $€ 32.50$}

\section{Steven Shapin}

It's said that you only live once, but a great scientist has many lives. These lives are not, however, personal existences but biographies, written by others, that make sense of the life and identify its historical significance. If the scientist is regarded as the founder of a discipline, or the author of a cherished theory or method, then biography can be a continuous creative act, changing in content and character as the science changes over time. Founding myths may be historically flawed but they often serve a function for the science concerned. And if the scientist is also a national hero, then even more is at play in these lives after death.

For Alexander von Humboldt (1769-1859), biographical life after death has been complex and contested. He was a polymath, or at least a poly-scientist; the only modern discipline that has plausibly laid claim to him as a founding figure is physical geography. His contributions to the field are marked by the names of the Humboldt Current along the west coast of South America, the Humboldt Glacier in Greenland, the Humboldt Mountain Range in Antarctica, and the Humboldt River and Humboldt Bay in the United States. But he also made contributions to natural history: a handful of plant and animal species are named after him, from the Humboldt penguin (Spheniscus humboldti) to the spectacular Humboldt lily (Lilium humboldtii). He was also a well-known traveller, diplomat, courtier, intellectual and popularizer of science.

Humboldt was a German who spent most of his productive life outside the country and wrote much of his scientific work in French. Together with his elder brother Wilhelm, a linguist who founded the University of Berlin, he has been a major German cultural icon, in the same pantheon as Goethe, Schiller and Beethoven.

But who was Alexander von Humboldt? Nicolaas Rupke doesn't seek a coherent answer to that question, nor does he think there can be one. He has not written a conventional biography but a life of lives, or 'metabiography', a meticulous study of how Humboldt's life was configured and reconfigured according to the sensibilities and needs of the changing cultural settings.

In the late nineteenth and early twentieth century, some German scientists saw Humboldt as a darwinian, even though he died before On the Origin of Species was published, and even though there is only patchy evidence of his dissent from the anti-evolutionist

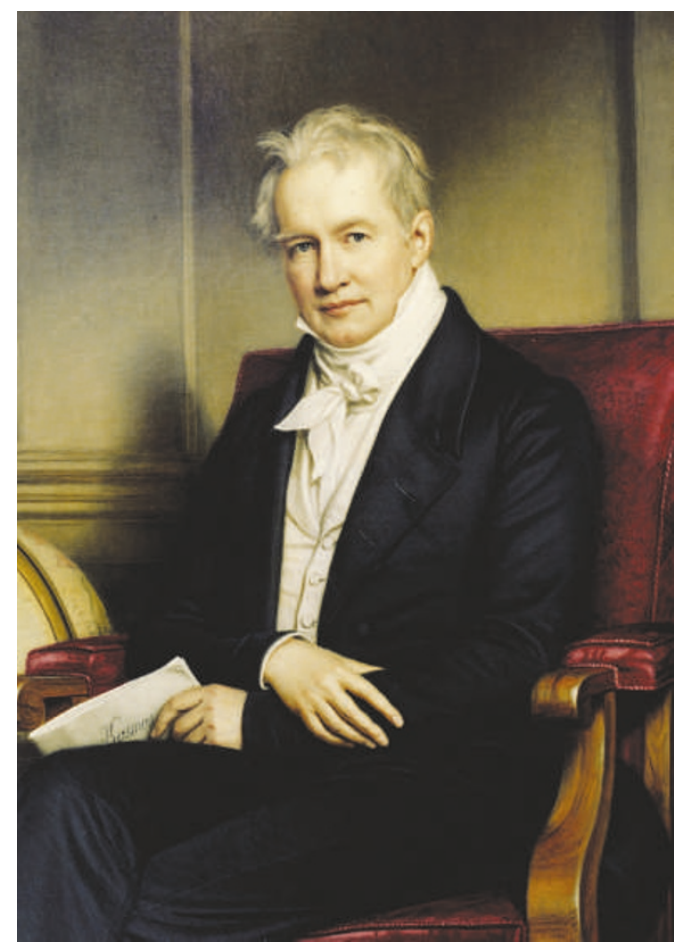

A changing picture: perceptions of Alexander von Humboldt depend on the social context of the viewer.

views of such naturalists as Louis Agassiz.

In the years leading up to German unification under Bismarck, Humboldt was a hero to liberal nationalists, despite having served as royal chamberlain to a deeply conservative Prussian court. The Nazis did their best to make Humboldt into a philosophical idealist of their preferred mystical type and, as Rupke says, "a herald of the Third Reich's new socio-political order". The 'de-Nazifiers' of the postwar Federal Republic saw Humboldt as a model of global cosmopolitanism and tolerance, a "good German", and even an active friend of the Jews. In the German Democratic

\section{A single survivor}

\section{Lonesome George: The Life and Loves of a Conservation Icon \\ by Henry Nicholls \\ Macmillan Science: 2006. 256 pp. £16.99 $\$ 24.95$}

\section{Rick Shine}

Conservation biology is a peculiar hybrid discipline, bounded on one side by hard empirical science and on the other by ageing actresses cuddling cute baby seals. As a result, conservation priorities reflect a sometimes bizarre balancing act between knowledge- and emotion-based perspectives of the natural world.
Republic, Humboldt's early career as a mining engineer was used to embellish his proletarian credentials, and his remarks against slavery established him, according to an East German text of the 1970s, as an opponent of "every form of racial discrimination, against every form of colonial expansion, and for the brotherhood of human beings of all colours".

More recently, the marxist Humboldt has been replaced with Humboldt the networking pioneer of globalized information economies, a 'green' Humboldt who viewed nature "as an ecological system", and a homosexual Humboldt whose long-suspected tendencies were 'outed' by several gay German writers, although this was disputed by scholars who either insisted on his heterosexuality or claimed that Humboldt had sacrificed sexual pleasures on the altar of scientific asceticism. Finally, the prisms of postmodernist scholarship have revealed a Humboldt who was a practitioner of disunified science and a man with no stable intellectual or political make-up at all, a ragbag of a man from whose life practically any evidence could be plucked to establish almost any identity, point or purpose.

Rupke is right to draw attention to the fact that shifting biographical traditions make one person have many lives, and his metabiography helps us to appreciate the historical instability of any scientific life, not just one as complex as Humboldt's. The past is never wholly a foreign country, and we make and remake past lives to suit our present purposes. No one whose life and work is of future interest can escape that fate. But one could also say that Rupke has given us a Humboldt just right for our own less certain and more self-conscious times - fractured, multiple and unstable.

Steven Shapin is Franklin L. Ford professor of the History of Science, Harvard University, 1 Oxford Street, Cambridge, Massachusetts 02138, USA.
This tension can occasionally result in an extraordinarily high public profile for an individual organism that can be argued to have some singular importance to conservation because it constitutes 'the last of its kind'. Some kind-hearted humans who are all too aware of the pain of loneliness on a personal level can readily empathize with the tragic circumstances of the last survivor. The animal can then take on iconic status - and (a cynic might say) attract publicity and financial resources out of all proportion to its actual conservation significance. The iconic individuals that evoke empathy from humans are 


\section{EXHIBITION \\ Martian arts}

The outwardly dry, forbidding territory of science might seem infertile soil for the whimsy of the newspaper cartoonist. But judging by Mars in their Eyes, an engaging exhibition at London's newly opened Cartoon Museum, missions to our planetary neighbours are a notable exception. After all, everybody knows that martian soils are populated by little green men.

As the martian physiognomy is unknown, it is a gift to a cartoonist's imagination. The inhabitants of the red planet are also used to great effect as mostly perplexed, sometimes mischievous commentators on their Earthly neighbours' aspirations. In a 1976 cartoon from The Philadelphia Inquirer, for instance, a martian housewife bangs irritatedly on the ceiling of her underground condo as the Viking 1 probe drills through her roof.
Not all missions to Mars were as successful as Viking 1, however. The bad luck and cock-ups along the way are, inevitably, mercilessly lampooned. "Do we measure light years in centimetres or feet and inches?" wonders a white-coated, bespectacled scientist from the pen of David Haldane of The Times in response to one egregious example the failure of NASA's Mars Climate Orbiter in 1999 following a disagreement between metric and imperial units.

The British-built Mars lander Beagle 2 (missing, presumed lost) features particularly prominently: its lead scientist, Colin Pillinger, is co-curator of the exhibition. A poignant item is

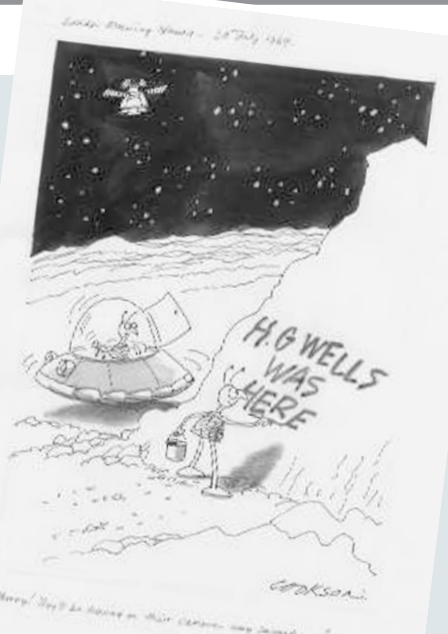

the pair of almost identical cartoons sketched in anticipation of Beagle's landing on Christmas Day 2003. Of these, only the one entitled Silent Night not Hark! Hear the Beagle Sing! - ever went to press.

Whether as a potted history of Mars

exploration, a primer of the press's view of science, or simply as a bit of fun, Mars in their Eyes is well worth a visit. It can be seen at the Cartoon Museum in London, a block away from the British Museum, until 1 July. R.W. www.cartooncentre.com

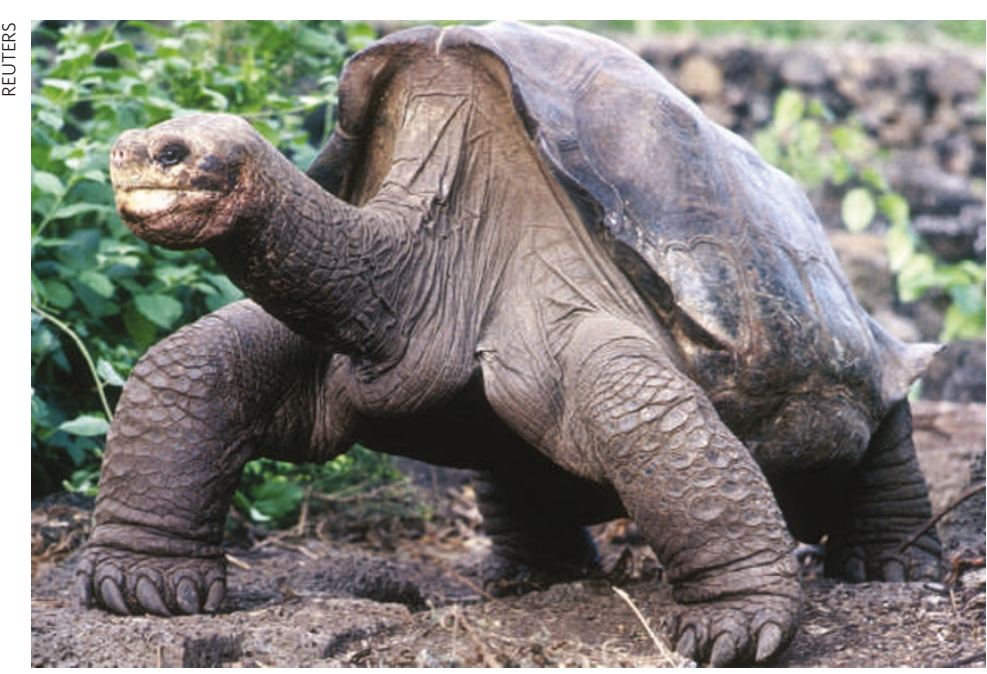

usually mammals or birds, but one reptile has captured hearts and minds - the forlorn figure of Lonesome George.

George is an adult male Galapagos tortoise, and is believed to be the last surviving member of a race that was abundant on Pinta Island before being slaughtered as a protein source for the crews of passing vessels. Closely related organisms from different islands in this archipelago differ in size and shape, an observation that Charles Darwin famously used as evidence for his theories of evolutionary change. Indeed, it was an observation about the distinctiveness of tortoises from different islands that first alerted Darwin to the possibility of such spatial variation. So Lonesome George captured in 1972, many decades after the Pinta race was thought to be extinct - is an icon for evolutionary biology as well as island conservation. As Henry Nicholls brings out in this delightfully written book, Lonesome George has also served as a lightning rod for scores of political, economic and scientific debates that have raged around the Galapagos as the islands have been transformed from a quiet site of scientific focus to a mecca for international tourism.

The science surrounding George is murky. How should you treat an internationally known conservation icon? Maintain him in luxury, where the tourists can pay to see him and be inspired about the urgent need for conservation efforts? Or release him back to freedom on his island, with females of a closely related lineage, at the risk that he will fall down a crevice and die? Or try to extract some of those Pinta-specific genes so his lineage can live on - at the risk of causing harm to this taciturn and decidedly non-amorous tortoise?

George continues to plod through his luxurious enclosure over the decades as the battle rages around him, and people come and go.
These include a young Swiss biologist who massaged George's genitals on a daily basis for six months to try to arouse his sexual passions; a local fisherman who sends death threats against George whenever the government tries to regulate the harvest of marine fauna; scientists whose ideas and suggestions about managing George's affairs rarely manage to penetrate the regulations that surround such an icon; and a series of park directors determined to protect George at all costs.

Nicholls skilfully and seamlessly brings in a broad array of snippets from recent scientific research in a diverse array of disciplines as he outlines the potential approaches that a conservation biologist might take to George's plight. However, it is not even clear that George really is the last Pinta tortoise, as opposed to a recent reintroduction, because the genetic differences between the Pinta and Espanola tortoises are so small. Such local populations are blinking out all around us and rarely receive much attention from conservation biologists, let alone the public.

If George were a small brown lizard (or even worse, a snake), nobody would care. But the giant tortoises of the Galapagos convey a sense of serene contemplation and prehistoric dignity, and it is difficult not to anthropomorphize and imagine the world from George's viewpoint. The literary device of placing a reptilian icon at the centre of a dynamic play about science, conservation and our attitudes to nature results in a highly readable book that has much to say about the ways we flounder around in our attempts to protect things that seem important to us.

Rick Shine is at the School of Biological Sciences, University of Sydney, Sydney, New South Wales 2006, Australia. 